\section{Estimation of vitamin D deficiency prevalence among Saudi children in Armed Forces Hospital and Riyadh Care Hospital in Riyadh, Kingdom of Saudi Arabia and its relation to type 1 diabetes mellitus}

Nouf A. ALkharashi, PhD.

\begin{abstract}
Objectives: To evaluate the prevalence of vitamin D deficiency among a group of Saudi children with type 1 diabetes mellitus (T1DM) in Armed Forces Hospital and Riyadh Care Hospital in Riyadh, Kingdom of Saudi Arabia.
\end{abstract}

Methods: The study was carried out in Riyadh Armed Forces Hospital and Riyadh Care Hospital in Riyadh, Kingdom of Saudi Arabia, from January to June 2017. This study included a total of 100 Saudi (50 males and 50 females) participants with T1DM, aged 2-12 years old. Hemoglobin A1c (HbA1c) levels, serum calcium phosphorous and $25(\mathrm{OH})$ vitamin $\mathrm{D}$ were analyzed.

Results: Seventy percent of the children with T1DM examined showed a reduced level of vitamin $\mathrm{D}$. Vitamin D deficiency was more common in female children compared than male. Serum $25(\mathrm{OH})$ vitamin $\mathrm{D}$ was significantly inversely associated with body mass index as well as HbAlc.

Conclusion: There is a concern that growing children with low vitamin $\mathrm{D}$ may be at higher risk for T1DM. It is necessary to further examine the mechanisms underlying vitamin D deficiency in T1DM children.

\section{Saudi Med J 2019; Vol. 40 (12): 1290-1293} doi:10.15537/smj.2019.12.24643

$\mathrm{D}$ iabetes mellitus (DM) is one of the most important public health problem worldwide. ${ }^{1}$ The Intern+ational Diabetes Federation (IDF) in 2017 estimated there to be 451 million people with diabetes worldwide in 2017, compared to 108 million in 1980 . By 2045 , this number is expected to increase to 693 million. ${ }^{2}$ Type 1 diabetes mellitus (T1DM) is characterized by hyperglycemia resulting from defects in pancreatic $\beta$-cells and represented $5-10 \%$ of the total cases of diabetes worldwide. Type 1 diabetes mellitus is the main type of diabetes in youth, representing $90 \%$ of diabetes cases in individuals children and adolescents than 20 years of age worldwide. ${ }^{3}$
A reduced risk of developing T1DM due to vitamin D supplementation during the first year of life was reported. ${ }^{4}$ The aim of the current study was to evaluate the prevalence of vitamin D deficiency among a group of Saudi children with T1DM attending outpatient clinics at Riyadh Armed Forces Hospital and Riyadh Care Hospital in Riyadh, Kingdom of Saudi Arabia.

Methods. A cross-sectional single-center randomly study was conducted in 100 Saudi (50 males and 50 females) participants with T1DM, aged 2-12 years old between January and June 2017 at Armed Forces Hospital and Riyadh Care Hospital, Riyadh, Kingdom of Saudi Arabia. Ethical approval was obtained from the Ethics Committee of the College of Science Research Center, King Saud University, Riyadh, Kingdom of Saudi Arabia.

Data collection and anthropometric analysis. Data were collected by questionnaire included: age, weight, height, gender, education level, and past and present medical history, sports activity, dietary sources of vitamin $\mathrm{D}$ and the frequency of exposure to sunlight. The exclusion criteria included: non-Saudis and those who were suffering from hepatic renal disease, metabolic bone disease, malabsorption, hypercortisolism, malignancy, immobility for more than one-week, or T2DM. The participants' anthropometric characteristics including weight, height and body mass index (BMI) were determined.

Blood collection and biochemical analysis. Approximately $2 \mathrm{ml}$ of venous blood samples were collected from participants who fasted for 8 hours, one with anticoagulant and the other without anticoagulant. The samples without anticoagulant were allowed to rest for 10 minutes, and then were centrifuged and immediately transported to Armed Forces Hospital, Riyadh, Kingdom of Saudi Arabia, and stored at $-20^{\circ} \mathrm{C}$ until analysis. Hemoglobin A1c (HbA1c) levels, serum $25(\mathrm{OH})$ vitamin $\mathrm{D}$, calcium and phosphorous were analyzed.

Statistical analysis. Categorical data are presented as frequencies and percentages (\%). Continuous data are presented as the mean \pm standard deviation $(\mathrm{SD})$ for normal variables, and non-Gaussian variables were presented as medians. All continuous variables were checked for normality using the Kolmogorov-Smirnov test. Non-Gaussian variables were log-transformed prior

Disclosure. Authors have no conflict of interests, and the work was not supported or funded by any drug company. 
to parametric analysis. Differences between groups were evaluated using a Student's t-test. Associations between variables were determined using Spearman's correlation. Univariate and multivariate linear regression analysis were performed to identify independent factors affecting $25(\mathrm{OH})$ vitamin $\mathrm{D}$. A $p$-value of $<0.05$ was considered significant.

Results. As shown in Table 1, there were 100 patients with T1DM, $50(50 \%)$ were males and $50(50 \%)$ were females aged 2-12 years old. Lips classified a level of $25(\mathrm{OH})$ vitamin $\mathrm{D}<12.5 \mathrm{nmol} / \mathrm{L}$ as a severe deficiency, $12.5-25 \mathrm{nmol} / \mathrm{L}$ as moderate deficiency, $25-50 \mathrm{nmol} / \mathrm{L}$ as mild deficiency, and $>50 \mathrm{nmol} / \mathrm{L}$ as normal. ${ }^{5}$ According to this classification, $11(11 \%)$ participants with T1DM had severe vitamin D deficiency, 30 (30\%) had moderate vitamin D deficiency, 29 (29\%) had mild vitamin D deficiency, and $30(30 \%)$ were normal. A
$25(\mathrm{OH})$ vitamin $\mathrm{D}$ level of females was significantly $(p=0.04)$ lower than males. Moderate vitamin D deficiency was significantly $(p=0.04)$ more frequent in females $(36 \%)$ than males $(24 \%)$.

As shown in Table 2, there was a significant $(p<0.0001)$ difference between $25(\mathrm{OH})$ vitamin $\mathrm{D}$ $<25 \mathrm{nmol} / \mathrm{L}$ and $\geq 25 \mathrm{nmol} / \mathrm{L}$ in regards to gender. A $25(\mathrm{OH})$ vitamin $\mathrm{D}$ level of $<25 \mathrm{nmol} / \mathrm{L}$ was more frequent in females $(50 \%)$ than males $(32 \%)$.

As shown in Table 3, serum $25(\mathrm{OH})$ vitamin D was positively correlated with age (10-12 years) among male and female participants and negatively with BMI $\left(>30 \mathrm{~kg} / \mathrm{m}^{2}\right)$ among male and female participant. Serum $25(\mathrm{OH})$ vitamin $\mathrm{D}$ was also negatively associated with $\mathrm{HbA1c}$ in male and female participants.

Discussion. The present study showed that a high prevalence of vitamin $\mathrm{D}$ deficiency among T1DM

Table 1 - General characteristics and biochemical parameters of study participants by gender.

\begin{tabular}{|c|c|c|c|c|}
\hline \multirow[t]{2}{*}{ Variable } & \multirow[t]{2}{*}{ Over all } & \multicolumn{2}{|c|}{ Gender } & \multirow[t]{2}{*}{$P$-value } \\
\hline & & Male & Female & \\
\hline & 100 & $50(50)$ & $50(50)$ & \\
\hline \multicolumn{5}{|l|}{ Age in years } \\
\hline $2-5$ & $37(37)$ & $17(34)$ & $20(40)$ & 0.09 \\
\hline $6-9$ & $35(35)$ & $20(40)$ & $15(30)$ & 0.07 \\
\hline $10-12$ & $28(28)$ & $13(26)$ & $15(30)$ & 0.08 \\
\hline \multicolumn{5}{|l|}{$B M I\left(\mathrm{~kg} / \mathrm{m}^{2}\right)$} \\
\hline $18.5-24.9$ & $71(71)$ & $35(70)$ & $36(72)$ & 0.42 \\
\hline $25-29.9$ & $17(17)$ & $10(20)$ & $7(14)$ & 0.38 \\
\hline$>30$ & $12(12)$ & $5(10)$ & $7(14)$ & 0.35 \\
\hline \multicolumn{5}{|l|}{ Serum $25(\mathrm{OH})$ vitamin $D$ deficiency (\%) } \\
\hline$<12.5 \mathrm{nmol} / \mathrm{L}$ & $11(11)$ & $4(8)$ & $7(14)$ & 0.06 \\
\hline $12.5-25 \mathrm{nmol} / \mathrm{L}$ & $30(30)$ & $12(24)$ & $18(36)$ & 0.04 \\
\hline $25-50 \mathrm{nmol} / \mathrm{L}$ & $29(29)$ & $14(28)$ & $15(30)$ & 1.0 \\
\hline$>50 \mathrm{nmol} / \mathrm{L}$ & $30(30)$ & $20(40)$ & $10(20)$ & $<0.001$ \\
\hline \multicolumn{5}{|l|}{ Duration of sun exposure } \\
\hline$<10 \mathrm{~min} /$ day & $60(60)$ & $20(40)$ & $40(80)$ & $<0.001$ \\
\hline $10-30 \mathrm{~min} /$ day & $12(12)$ & $7(14)$ & $5(10)$ & 0.19 \\
\hline$>30 \mathrm{~min} /$ day & $28(28)$ & $23(46)$ & $5(10)$ & $<0.001$ \\
\hline \multicolumn{5}{|l|}{ Dairy products } \\
\hline Daily intake & $53(53)$ & $28(56)$ & $25(50)$ & 0.08 \\
\hline Twice per week & $45(45)$ & $20(40)$ & $25(50)$ & 0.09 \\
\hline None & $2(2)$ & $2(4)$ & 0 & 0.06 \\
\hline \multicolumn{5}{|l|}{ Seafood } \\
\hline Daily intake & $12(12)$ & $7(14)$ & $5(10)$ & 0.08 \\
\hline Twice per week & 77 (77) & $39(78)$ & $38(76)$ & 1.0 \\
\hline None & $11(11)$ & $4(8)$ & $7(14)$ & 0.07 \\
\hline \multicolumn{5}{|l|}{ Vitamin supplement } \\
\hline Yes & $86(86)$ & $44(88)$ & $42(84)$ & 0.09 \\
\hline No & $14(17)$ & $6(12)$ & $8(16)$ & 0.07 \\
\hline Serum $25(\mathrm{OH})$ vitamin D level nmol/L, Mean \pm SD & $35.1 \pm 1.4$ & $34.1 \pm 1.8$ & $32.1 \pm 2.6$ & 0.04 \\
\hline Serum calcium $(2.2-2.6 \mathrm{mmol} / \mathrm{L}), \mathrm{Mean} \pm \mathrm{SD}$ & $1.8 \pm 0.5$ & $1.8 \pm 0.3$ & $1.9 \pm 0.2$ & 0.92 \\
\hline Serum phosphorus $(0.8-1.4 \mathrm{mmol} / \mathrm{l})$, Mean $\pm \mathrm{SD}$ & $1.4 \pm 0.2$ & $1.3 \pm 0.3$ & $1.1 \pm 0.2$ & 0.85 \\
\hline HbAlc (4-5.6\%), Mean \pm SD & $8.6 \pm 2.2$ & $8.5 \pm 1.4$ & $8.7 \pm 1.9$ & 1.0 \\
\hline
\end{tabular}


children. Overall, $70 \%$ of participants were vitamin D deficient. In agreement with these findings, in Qatari children under 16 years old, vitamin D deficiency was considerably higher in T1DM children (90.6\%) compared with non-diabetic children $(85.3 \%) .{ }^{6}$ In a previous study of Saudi children with T1DM, 77\%

Table 2 - Differences between vitamin D level groups.

\begin{tabular}{|c|c|c|c|}
\hline \multirow[t]{3}{*}{ Parameters } & \multicolumn{2}{|c|}{$25(\mathrm{OH})$ vitamin D levels $(\mathrm{nmol} / \mathrm{L})$} & \multirow[t]{2}{*}{$P$-value } \\
\hline & $<25$ & $\geq 25$ & \\
\hline & \multicolumn{2}{|c|}{ Mean \pm SD } & \\
\hline $\mathrm{N}(\%)$ & $41(41)$ & $59(59)$ & \\
\hline Male/female, n (\%) & $16(32) / 25(50)$ & $34(68) / 25(50)$ & $<0.0001$ \\
\hline Age (years) & $4.5 \pm 1.2$ & $6.2 \pm 2.5$ & 0.06 \\
\hline $\mathrm{BMI}\left(\mathrm{kg} / \mathrm{m}^{2}\right)$ & $18.9 \pm 2.9$ & $19.8 \pm 2.7$ & 0.82 \\
\hline $\begin{array}{l}\text { Serum calcium }(2.2- \\
2.6 \mathrm{mmol} / \mathrm{L})\end{array}$ & $1.8 \pm 0.5$ & $1.9 \pm 0.2$ & 0.33 \\
\hline $\begin{array}{l}\text { Serum phosphorus } \\
(0.8-1.4 \mathrm{mmol} / \mathrm{L})\end{array}$ & $1.3 \pm 0.1$ & $1.5 \pm 0.3$ & 0.63 \\
\hline HbAlc $(4-5.6 \%)$ & $8.9 \pm 2.3$ & $8.2 \pm 1.3$ & 0.07 \\
\hline
\end{tabular}

Table 3 - Bivariate relationship between serum $25(\mathrm{OH})$ vitamin $\mathrm{D}$ as the dependent variable and the anthropometric and biochemical parameters of study participants by gender $(\mathrm{N}=100)$.

\begin{tabular}{|c|c|c|c|}
\hline Variables & Over all & $\begin{array}{c}\text { Males } \\
(\mathrm{n}=50)\end{array}$ & $\begin{array}{c}\text { Females } \\
(\mathrm{n}=50)\end{array}$ \\
\hline \multicolumn{4}{|l|}{ Age in years } \\
\hline $2-5$ & 0.16 & 0.29 & 0.18 \\
\hline $6-9$ & 0.22 & 0.12 & 0.13 \\
\hline $10-12$ & $0.30^{*}$ & 0.16 & $0.17^{*}$ \\
\hline \multicolumn{4}{|l|}{$B M I(\mathrm{~kg} / \mathrm{m} 2)$} \\
\hline Normal (18.5-24.9 & -0.16 & -0.18 & -0.08 \\
\hline Overweight (25-29.9) & -0.27 & -.017 & -0.12 \\
\hline Obese $(>30)$ & $-0.29^{*}$ & $-0.18^{*}$ & $-0.11^{*}$ \\
\hline \multicolumn{4}{|l|}{ Duration of sun exposure } \\
\hline$<10 \mathrm{~min} /$ day & 0.29 & 0.14 & 0.21 \\
\hline $10-30 \mathrm{~min} /$ day & 0.18 & 0.13 & 0.11 \\
\hline$>30 \mathrm{~min} /$ day & 0.31 & 0.22 & 0.15 \\
\hline \multicolumn{4}{|l|}{ Dairy products } \\
\hline Daily intake & 0.29 & 0.13 & 0.21 \\
\hline Twice per week & 0.08 & 0.03 & 0.12 \\
\hline None & 0.15 & 0.12 & 0.11 \\
\hline \multicolumn{4}{|l|}{ Seafood } \\
\hline Daily intake & 0.39 & 0.24 & 0.11 \\
\hline Twice per week & 0.14 & 0.5 & 0.7 \\
\hline None & 0.31 & 0.22 & 0.15 \\
\hline \multicolumn{4}{|l|}{ Vitamin supplement } \\
\hline Yes & $0.32^{*}$ & $0.24^{*}$ & 0.21 \\
\hline No & 0.13 & 0.8 & 0.6 \\
\hline Serum calcium $(2.2-2.6 \mathrm{mmol} / \mathrm{L})$ & 0.21 & 0.13 & 0.12 \\
\hline Serum phosphorus $(0.8-1.4 \mathrm{mmol} / \mathrm{l})$ & 0.35 & 0.12 & 0.14 \\
\hline & $-0.13^{*}$ & $-0.08^{*}$ & $-0.05^{*}$ \\
\hline \multicolumn{4}{|c|}{ Data presented as coefficient (R). *denotes significance at $p<0.05$ level. } \\
\hline
\end{tabular}

of the children had a low level of $25(\mathrm{OH})$ vitamin $\mathrm{D} .^{7}$ Another study showed that $84 \%$ of Saudi children with T1DM versus $59 \%$ of healthy children were vitamin D deficient. ${ }^{8}$

Preclinical studies described that vitamin D seems to play a regulatory role in insulin secretion and can prevent the death of pancreatic $\beta$-cells. ${ }^{9,10}$ One study on 10,366 children in Finland over 31 years indicated that 2000 IU of vitamin D3 per day throughout the first year of life can reduce the risk of T1DM by $78 \% .{ }^{11}$

In our study, the prevalence of vitamin $\mathrm{D}$ deficiency was significantly $(p=0.04)$ higher among female than male children with T1DM; furthermore, there was a significant positive correlation between $25(\mathrm{OH})$ vitamin D and age (10-12 years) with regard to female. These results were consistent with previous studies reported that the frequency of vitamin $\mathrm{D}$ deficiency was significantly $(p<0.0001)$ higher in females $(77 \%)$ than in males (37\%) with T1DM. ${ }^{12}$ A higher incidence of vitamin $\mathrm{D}$ deficiency among females in children with T1DM might be related to limited exposure to sunlight, especially during summer, and limited intake of foods and supplements. Vitamin D can be obtained endogenously from sunlight exposure through synthesis. ${ }^{13}$ The majority of females with T1DM had only limited exposure to sunlight, because of the cultural practice of wearing protective dress to cover most of the body. These findings are supported by a past study that showed that wearing concealing clothing and restriction of outdoor activities had adverse effects on $25(\mathrm{OH})$ vitamin D levels among Saudi Arabian adolescents. ${ }^{14}$

Our study indicated that serum $25(\mathrm{OH})$ vitamin D was significantly inversely associated with BMI in male and female participants. These findings are supported by a past study reported that a significant predictor of vitamin D deficiency in BMI. ${ }^{15}$

Study limitations. The small sample size and crosssectional-based study cannot suggest any cause of vitamin $\mathrm{D}$ deficiency and limits the application of our results to the Saudi population. Enlargements in the size of the groups are needed to investigate the mechanisms underlying vitamin $\mathrm{D}$ deficiency in T1DM children.

In conclusion, vitamin D deficiency was common among Saudi children with T1DM. Overall, the level of vitamin D deficiency was found to be $77 \%$ with more common in female than those male. There was significant inverse association between serum $25(\mathrm{OH})$ vitamin D level and BMI as well as HbA1c. There is a concern that growing children with low vitamin $\mathrm{D}$ may be at higher risk for T1DM. It is necessary to further examine the mechanisms underlying vitamin $\mathrm{D}$ deficiency in T1DM children. 
Acknowledgment. The author gratefully acknowledge the support of Deanship of Scientific Research at Prince Sattam bin Abdulaziz University, Riyadh, Kingdom of Saudi Arabia.

Received 22nd August 2019. Accepted 13th October 2019.

From the Department of Home Economics, College of Education - Dilam, Prince Sattam Bin Abdulaziz University, Riyadh, Kingdom of Saudi Arabia.

Address correspondence and reprints request to: Dr. Nouf A. ALkharashi, Department of Home Economics, College of Education - Dilam, Prince Sattam Bin Abdulaziz University, Riyadh, Kingdom of Saudi Arabia. E-mail: noufalkharashi84@gmail.com

ORCID ID: https://orcid.org/0000-0002-5760-1996

\section{References}

1. Tabish SA. Is diabetes becoming the biggest epidemic of the twenty-first century? IInt J Health Sci (Qassim) 2007; 1: V-VIII.

2. Cho N, Shaw J, Karuranga S, Huang Y, da Rocha Fernandes J, Ohlrogge A, et al. IDF Diabetes Atlas: global estimates of diabetes prevalence for 2017 and projections for 2045. Diabetes Res Clin Pract 2018; 138: 271-281.

3. Craig ME, Hattersley A, Donaghue KC. Definition, epidemiology and classification of diabetes in children and adolescents. Pediatric diabetes 2009; 10: 3-12.

4. Group ESS. Vitamin D supplement in early childhood and risk for Type I (insulin-dependent) diabetes mellitus. Diabetologia 1999; 42: 51-54.

5. Lips P. Which circulating level of 25-hydroxyvitamin D is appropriate? J Steroid Biochem Mol Biol 2004; 89-90: 611-614.

6. Bener A, Alsaied A, Al-Ali M, Al-Kubaisi A, Basha B, Abraham $A$, et al. High prevalence of vitamin $D$ deficiency in type 1 diabetes mellitus and healthy children. Acta Diabetol 2009; 46: 183-189.
7. Al-Agha AE, Ahmad IA. Association among vitamin D deficiency, type 1 diabetes mellitus and glycemic control. $J$ Diabetes Metab 2015; 6: 2.

8. Bin-Abbas BS, Jabari MA, Issa SD, Al-Fares AH, Al-Muhsen S. Vitamin D levels in Saudi children with type 1 diabetes. Saudi Med J 2011; 32: 589-592.

9. Riachy R, Vandewalle B, Moerman E, Belaich S, Lukowiak B, Gmyr V, et al. 1,25-Dihydroxyvitamin D 3 protects human pancreatic islets against cytokine-induced apoptosis via downregulation of the Fas receptor. Apoptosis 2006; 11: 151-159.

10. Kadowaki S, Norman AW. Dietary vitamin D is essential for normal insulin secretion from the perfused rat pancreas. J Clin Invest 1984; 73: 759-766.

11. Hyppönen E, Läärä E, Reunanen A, Järvelin M-R, Virtanen SM. Intake of vitamin $\mathrm{D}$ and risk of type 1 diabetes: a birthcohort study. Lancet 2001; 358: 1500-1503.

12. Aljabri KS, Bokhari S, Alqurashi K. Vitamin D Status in Saudi patients with type 1 diabetes mellitus. Open J Endocr Metab Dis 2013; 3: 137-143.

13. Andıran N, Çelik N, Akça H, Doğan G. Vitamin D deficiency in children and adolescents. J Clin Res Pediatr Endocrinol 2012; 4: 25.

14. Mishal A. Effects of different dress styles on vitamin D levels in healthy young Jordanian women. Osteoporos Int 2001; 12: 931-935.

15. Al-Daghri NM, Al-Attas OS, Al-Okail MS, Alkharfy KM, Al-Yousef MA, Nadhrah HM, et al. Severe hypovitaminosis D is widespread and more common in non-diabetics than diabetics in Saudi adults. Saudi Med J 2010; 31: 775-780. 